\title{
Practice of Iranian Adolescent Girls Regarding Puberty and Menstrual Hygiene and its Predictors, 2013
}

\author{
Sakineh Mohammad-Alizadeh Charandabi ${ }^{1}$ Mojgan Mirghafourvand ${ }^{2}$, Sima Saghi ${ }^{3}$, \\ Simin Seidi ${ }^{2}$, Azad Rahmani ${ }^{4}$, Somaieh Zareie ${ }^{3}$
}

Article History:
Received 15 November 2013
Accepted 2 February 2014
Revised 20 January 2014
Available online 4 February 2014
Keywords:
Adolescent Girls
Menstrual Hygiene
Practice
Puberty
Corresponding Author:
Mojgan Mirghafourvand,
Midwifery Department, Tabriz
University of Medical Sciences,
Tabriz, Iran.
Tel: +989143206121
Email:
mirghafourvandm@tbzmed.ac.ir

\section{Article History:}

Received 15 November 2013

Accepted 2 February 2014

Revised 20 January 2014

Keywords

Adolescent Girls

Menstrual Hygiene

Practice

Corresponding Author:

Mojgan Mirghafourvand,

Midwifery Department, Tabriz

Tabriz, Iran.

Tel: +989143206121

mirghafourvandm@tbzmed.ac.ir

\begin{abstract}
Objectives: Adolescence is a unique period in life cycle. During this period, adolescents face with many behavioural challenges. This study aimed to determine adolescent girls' practice regarding puberty and menstrual hygiene, as well as its relationship with socio-demographic characteristics.

Materials and Methods: This cross-sectional study was conducted on 1017 female students who were studying at second and third grade of secondary schools in Tabriz, 2013. Samples were selected randomly. Questionnaires used in the study were the practice and socio-demographic questionnaires. General linear model was used to determine predictors of practice.

Results: Mean (SD) of practice score in adolescent girls was 64.2 (12.1) from attainable score of $0-100$. More than half of students (56.7\%) had moderate practice. According to adjusted general liner model, variables of being in second class, having a father with elementary education or illiterate, living in undesirable economic status, having peer groups and friends as main source of information, having insufficient information about puberty had negative relationships with practice score. While, there was a positive relationship between age at menarche and practice score $(\mathrm{p}<0.05)$.

Conclusion: The findings show that the practice of adolescents about puberty and menstrual hygiene is moderate. Thus, it is necessary to educate the girls about puberty and menstrual hygiene to enable them to have a healthy reproductive life in future.
\end{abstract}

1- Research Center of Social Determinants of Health, Nursing and Midwifery Faculty, Midwifery Department, Tabriz University of Medical Sciences, Tabriz, Iran.

2- Midwifery Department, Tabriz University of Medical Sciences, Tabriz, Iran.

3- Master of Midwifery Student, Student Research Committee, Tabriz University of Medical Sciences, Tabriz-Iran.

4- Nursing Department, Tabriz University of Medical Sciences, Tabriz, Iran. 


\section{Introduction:}

The World Health Organization (WHO) defines adolescence as the period of life between 10 and 19 years of age (1). Adolescents are considered one of the most important age groups in any society, and the health of adolescents is an essential foundation for every society's health (2). Based on the latest national census, there are nearly more than three million adolescent girls aged 10 to 19 in Iran (3).

Adolescence is a transition period between childhood and adulthood, which play crucial role in the life of human beings. This period is an important physiological phase of life characterized by a rapid growth and development in physical and psychological domains (4). The hormonal and physical changes of puberty will have a direct effect on some aspects of emotion and behaviour (5).

Adolescents have specific health and developmental needs, and may face behavioural challenges that hinder their well being (1). Unfortunately, the most of girls do not have accurate and enough information about puberty and its related healthy behaviours $(6,7)$. Also, in this period, many adolescents are affected by some health threatening behaviours such as excess food consumption and physical inactivity (8). As well as, many adolescents face pressures to use alcohol, cigarettes, or other drugs and to initiate sexual relationships at earlier ages, putting themselves at high risk for sexually transmitted infections, including HIV (2).

Studies showed that counseling can change adolescents' behaviour resulting in improving different aspects of their health (9). Other studies showed that many health problems can be prevented by improving healthy behaviours in adolescents (10-12). Thus, healthy practice in this period of life is important (13).

A research in Nigeria (2000) showed that $84 \%$ of adolescents had not been prepared psychologically for the first menses and most of them did not have accurate practice during puberty (14). Also, a study done by Abdollahi et al (2003) showed most of girls had inaccurate practice regarding puberty and menstruation (15). Thus, considering the importance of this period of life as a foundation for present and future health and effect of proper practice on improving different domains of health, this study was conducted with aim to determine adolescent girls' practice regarding puberty and menstrual hygiene and its relationship with socio-demographic characteristics.

\section{Material \& Methods:}

Study design and sampling :

This cross-sectional study was done on 1017 female students who were studying at the second and third grade of secondary schools in Tabriz-Iran, 2013. Samples were selected randomly. First, 23 schools that had at least 100 students, were chosen among 99 governmental, and non-governmental secondary schools from 5 educational regions in Tabriz; then, one-third of students in second grade and one-third of students in third grade were chosen by stratified random method. Informed consent was obtained from all participants.

\section{Data Collection :}

Tools used in the study were sociodemographic and practice questionnaires which were developed by the researcher team.

Socio-demographic questionnaire included student's age, grade of education; age, education and job of father and mother; economic status, people lived with students, child's rank, number of sisters and brothers, previous information about puberty, main source and preferred source of information about puberty, sufficiency of previous information, age at menarche and feeling at the onset of menarche.

The practice questionnaire contained 20 items. All the items were scored based on a 4-point Likert scale $(1=$ never, $2=$ sometimes, $3=$ often, $4=$ always). The item of 15 and 20 were scored reversely. Sum of each participants' score were calculated from attainable score of 0-100 [(raw sum score -20$) * 100 / 60)$. The scores between 0 to 33.3 were considered as poor practice, 33.4 to 66.7 as moderate and 66.7 or higher as good practice.

Content and face validity were measured to determine the validity of the questionnaire. Content validity index (CVI) was determined 
according to three criteria of relevancy, clarity and simplicity. CVI was 0.89 for practice questionnaire. Pre-test and posttest were implemented on 30 adolescents to determine the reliability (intraclass correlation coefficient, ICC) and internal consistency (Cronbach's $\alpha$ coefficient). ICC (Confidence Interval 95\%) and Cronbach's $\alpha$ were 0.88 (0.72 to 0.95$)$ and 0.84, respectively.

\section{Data analysis :}

SPSS ver. 13 was used for data analysis. In order to describe the socio-demographic characteristics and practice status, we used descriptive statistics; i.e. absolute and relative frequency, as well as central and dispersion indexes (e.g., mean and standard deviation). First, we implemented bivariate statistical tests such as t-test, Pearson test, and one way analysis of variance to determine the unadjusted relationship between socio-demographic characteristics and practice. Then, the independent variables that had $\mathrm{p}<0.05$ in the bivariate tests were integrated into the multivariate general linear model in order to control the confounding variables and measure the respective effects of the independent variables (socio-demographic characteristics) on the dependent variables (practice).

\section{Results:}

\section{Socio-demographic characteristics :}

Mean (SD) age of participants was 13.1(0.7). Menarche in one-third of students (32\%) was happened in 24-48 weeks ago. More than half of adolescents (58\%) were in the third class. The age of mothers in more than half of adolescents (62\%) were 30-40 years. More than one-fourth of mothers and fathers (32\% and $35 \%$, respectively) had high school or diploma degree. About two-third of participants (66\%) described their economic status as desirable. The most of adolescents (92\%) were living with their parents. Although $94 \%$ of the participants mentioned acquiring some previous information about puberty, only $26 \%$ of them assessed their information as sufficient. About half of them (51\%) were first child in their family. Mothers were main source of information in more than half of participants (56\%) and majority of adolescents (65\%) preferred to gain information from their own mother or sister. Majority of adolescents (61\%) had moderate information about puberty. More than half of them (56\%) mentioned experience of unpleasure feeling at the onset of menarche. Practice status :

Mean (SD) score of practice status was 64.2 (12.1). More than half of adolescents $(56.7 \%)$ had moderate practice. High majority of participants (95.6\%) were using disposable pads during menstruation. Only $11.3 \%$ of them mentioned that they never used greasy and salty foods, pittza and sausage (Table 1 ).

Relationship between practice score with socio-demographic characteristics :

Results of bivariate analysis showed that there was a statistically significant relationship $(\mathrm{p}<0.05)$ between practice and age, number of family, age at menarche, educational grade, economic status, father's and mother's education, sufficiency of previous information and main source of information about puberty (Table 2 and 3 ). These variables were entered to the adjusted general liner model for controlling confounder variables. The results of adjusted general linear model showed that being in second class, having a father with elementary education or illiterate, living in undesirable economic status, having peer group and friends as the source of main information, having insufficient information about puberty had negative relationship with practice, while there was a positive relationship between age at menarche and practice score $(\mathrm{p}<0.05)$ (table 4$)$.

\section{Discussion:}

The results of this study showed that the student's practice was moderate. Variables of age at menarche, education grade, father's education, family economic status, main source of information about puberty hygiene and sufficiency of information about puberty were found to be predictors of practice in adolescents.

Findings of this study about practice status were consistent with results of studies done by Alavi et al. (2008) in Tehran (16) and Bilani et al. (2008) in Kerman (17). 
Malekshahi et al. (2005) in their research in Khorramshahr reported that most of the participants had weak practice about menstruation (18). These findings indicated that Iranian adolescents do not have proper practice regarding puberty and menstrual hygiene and their knowledge and practice should be promoted using attractive educational methods.

In this study, more than half of students mentioned experience of unpleasure feeling at first menstruation. This finding is in line with the results of other studies in this field $(16,18,19)$ that indicate insufficient knowledge of adolescents about puberty and lack of attention to their psychological issues. Thus, it should be emphasized to start education of puberty health from younger ages. If adolescent girls are made aware of menstrual hygiene from the early adolescent period, the menarche will not be a shock for them and they will also be better equipped to cope up with the situation.

In this study, students of third grade had better practice than second grade. Previous studies have indicated that increasing age enhances the behaviours $(20,21)$. The improvement of practice with increasing grade of education may be related to the effect of longer experience of menstruation cycles.

Father's education was among other effective variables of practice: the adolescents with university educated fathers achieved higher score. This has also been suggested as one of the effective factors for practice and health behaviours in previous studies in Iran $(16,22)$ and other countries (14). These results indicate that the adolescents' practice could be improved by promoting of parent's literacy.

In the present study, participants with desirable economic status had better practice. This finding was consistent with the results of other studies $(23,24)$. Gupta and Sinha study (2006) showed that socioeconomic factor significantly influences source of information and level of awareness of menarche and reproduction among adolescent girls (25).

The main source of information and sufficiency of acquired information were effective factors on practice. In this study, mothers were main source of information for girls and the majority of girls preferred to get information from her mother or sister. This finding and also similar results in other studies (26) highlight family especially mother role in education of girls about puberty. Thus, strengthening relationship between mothers and their girls and removing barriers such as shy or mother unawareness about health outcomes of this period should be included in educational plans for mothers.

According to this research, the girls that experienced menarche in older age had better practice. This finding is consistent with the Koivusilta et al. (27) and KaltialaHeino et al. (28) studies. Dick et al (2000) reported that early menarche was related with early and repetitive using of cigar and alcohol (29). This finding showed that health professionals should have special attention to practice and needs of adolescents with early menarche.

In this study, the most of girls was using sausage, pizza and cola. This result is in line with the study by Irinoye et al, who also found that feeding practice in adolescent girls was undesirable (19). Since such nutrient-poor foods influence negatively on health, it is necessary to plan educational interventions and adopting approaches to improve nutrition in adolescents.

Although the most of girls used disposable pads during menstruation, which is consistent with other studies $(14,19)$, but only one fourth of them take the bath daily or every other day in this period that is accordance with Abdollahi (15) and Koff (30) studies. This finding highlights their vulnerability for some complications such as infectious disease and infertility in future (14).

It must be noted that due to the crosssectional nature of our study, the relationships observed between the practice and the associated factors cannot be interpreted as causal relation. Considering the importance of healthy practice during adolescence, their evaluation in boy adolescents is recommended. Future studies for finding high effective educational 
methods on adolescents' practice are recommended.

\section{Conclusion :}

The findings show that the practice of adolescents about puberty and menstrual hygiene is moderate. They highlight the needs of the adolescent girls to have accurate and adequate information about puberty and menstrual hygiene. Thus, it is necessary to implement strategies for improving of adolescents' practice. Mothers need to be equipped with the correct information and communication skills to help their adolescent daughters to get ready for this important physiological event in their life. This can be achieved through special educational programs in school curriculum, along with the involvement of parents, particularly mothers.

\section{Conflicts of interest:}

Authors declare that there is no any conflict of interest.

\section{Acknowledgments:}

This research was sponsored by Tabriz University of Medical Sciences (Code: 91203). The assistance of the head office of the Education Ministry of Tabriz City, the personnel from the girls' secondary schools, and all participants in this study is greatly appreciated.

Table 1. The status of practice in adolescent girls $(n=1017)$

\begin{tabular}{|c|l|c|c|c|c|}
\hline & \multicolumn{1}{|c|}{ Item } & $\begin{array}{c}\text { Never } \\
\mathrm{N}(\%)\end{array}$ & $\begin{array}{c}\text { Sometimes } \\
\mathrm{N} \mathrm{( \% )}\end{array}$ & $\begin{array}{c}\text { Often } \\
\mathrm{N}(\%)\end{array}$ & $\begin{array}{c}\text { Always } \\
\mathrm{N}(\%)\end{array}$ \\
\hline 1 & $\begin{array}{l}\text { In toilet, I first wash perinea then anal, i.e., } \\
\text { wash front part then back. }\end{array}$ & $122(12.5)$ & $84(8.6)$ & $238(24.4)$ & $530(54.4)$ \\
\hline 2 & I dry underwear with iron or sunlight. & $144(14.3)$ & $123(12.2)$ & $303(30.1)$ & $438(43.5)$ \\
\hline 3 & I dry perinea after washing. & $130(13.0)$ & $130(13.0)$ & $241(24.1)$ & $497(49.8)$ \\
\hline 4 & I use private towel. & $59(5.9)$ & $59(5.9)$ & $144(14.3)$ & $746(74.0)$ \\
\hline 5 & I drink 6-8 glasses of water every day. & $71(7.1)$ & $175(17.6)$ & $253(25.4)$ & $496(49.8)$ \\
\hline 6 & $\begin{array}{l}\text { I eat 9 to 11 servings of grain like bread, } \\
\text { rice, pasta daily (1 serving of grain equals } \\
\text { to 1 slice of bread, 1/2 glass of cooked rice } \\
\text { or pasta). }\end{array}$ & $81(8.1)$ & $238(23.7)$ & $477(47.5)$ & $208(20.7)$ \\
\hline 7 & $\begin{array}{l}\text { I eat 3 or 4 servings of fruits daily (1 } \\
\text { serving of fruits equals to 1 moderate } \\
\text { fruit, 1/2 glass of juice or 1/4 glass of } \\
\text { dried fruit like dried figs). }\end{array}$ & $46(4.6)$ & $190(19.0)$ & $417(41.6)$ & $349(34.8)$ \\
\hline 8 & $\begin{array}{l}\text { I eat 4 or 5 servings of vegetables (1 } \\
\text { serving of vegetables equals to 1 glass of } \\
\text { row vegetables or 1/2 glass of cooked } \\
\text { vegetables). }\end{array}$ & $115(11.4)$ & $335(33.2)$ & $431(42.8)$ & $127(12.6)$ \\
\hline 9 & I wear comfortable and cotton clothes. & $23(2.3)$ & $81(8.1)$ & $288(28.8)$ & $609(60.8)$ \\
\hline 10 & $\begin{array}{l}\text { I take a bath daily or every other day } \\
\text { during menstruation. }\end{array}$ & $284(28.7)$ & $251(25.4)$ & $243(24.6)$ & $211(21.3)$ \\
\hline 11 & $\begin{array}{l}\text { I do exercise like walking, at least 20 } \\
\text { minutes every day. }\end{array}$ & $224(22.7)$ & $288(29.1)$ & $275(27.8)$ & $201(20.3)$ \\
\hline 12 & $\begin{array}{l}\text { I do not drink tea 1 hour before and after } \\
\text { food. }\end{array}$ & $295(29.6)$ & $148(14.9)$ & $210(21.1)$ & $342(34.4)$ \\
\hline 13 & $\begin{array}{l}\text { I express my feeling without shouting and } \\
\text { appropriately when being angry. }\end{array}$ & $278(27.8)$ & $192(19.2)$ & $29529.5)$ & $234(23.4)$ \\
\hline
\end{tabular}




\begin{tabular}{|c|l|c|c|c|c|}
\hline 14 & $\begin{array}{l}\text { I eat 3 servings of milk, yoghurt or cheese } \\
\text { daily (1 serving of dairy equals to 1 glass } \\
\text { of milk or yoghurt, } 3 \text { cm cube (1 box of } \\
\text { matches) of chesse or 1/2 glass of ice- } \\
\text { cream). }\end{array}$ & $97(9.7)$ & $229(23.0)$ & $352(35.3)$ & $319(32.0)$ \\
\hline 15 & I use fat \& salty foods, pizza and sausage.** & $113(11.3)$ & $309(30.9)$ & $421(42.1)$ & $156(15.6)$ \\
\hline 16 & $\begin{array}{l}\text { I use disposable pads during } \\
\text { menstruation. }\end{array}$ & $9(0.9)$ & $13(1.3)$ & $21(2.1)$ & $936(95.6)$ \\
\hline 17 & $\begin{array}{l}\text { I wash my hands with soap before and } \\
\text { after changing my pad. }\end{array}$ & $5(0.5)$ & $10(1.0)$ & $45(4.5)$ & $943(94.0)$ \\
\hline 18 & $\begin{array}{l}\text { I eat 2-3 servings of meat, hen, fish, bean, } \\
\text { egg or nuts daily (1 serving of protein } \\
\text { equals to 1/2 glass of cooked bean, 30 } \\
\text { grams of meat, 2 eggs or 1/2 glass of nuts. }\end{array}$ & $52(5.2)$ & $185(18.4)$ & $514(51.1)$ & $254(25.3)$ \\
\hline 19 & $\begin{array}{l}\text { I consult with my family and educator } \\
\text { about my unpleasure sense. }\end{array}$ & $211(20.9)$ & $215(21.3)$ & $266(26.4)$ & $317(31.4)$ \\
\hline 20 & I drink cola.** & $173(17.2)$ & $314(31.2)$ & $342(34.0)$ & $178(17.7)$ \\
\hline \multicolumn{4}{|l|}{ Mean (standard deviation)=64.2(12.0) from attainable score of $0-100$} \\
\hline
\end{tabular}

*Number (Percent)

** Reverse items

Table 2 Relationship between qualitative socio-demographic characteristics and practice score in adolescent girls according to bivariate tests.

\begin{tabular}{|c|c|c|c|c|c|}
\hline Characteristics & $\mathrm{n}$ & $\begin{array}{l}\text { Mean } \\
(\mathrm{SD})\end{array}$ & Characteristics & $\mathrm{n}$ & Mean (SD) \\
\hline Educational grade* & & & People lived with student & & \\
\hline 7th year & 416 & $\begin{array}{c}62.4 \\
(12.8)\end{array}$ & Both of father and mother & 931 & $\begin{array}{c}64.2 \\
(12.0)\end{array}$ \\
\hline 8th year & 601 & $\begin{array}{c}65.4 \\
(11.3)\end{array}$ & Only with father or mother & 48 & $\begin{array}{c}65.2 \\
(10.1)\end{array}$ \\
\hline Father's education* & & & Stepfather or stepmother & 6 & $65.5(9.6)$ \\
\hline Illiterate \& elementary & 242 & $\begin{array}{c}60.9 \\
(13.1)\end{array}$ & Living with relatives & 30 & $\begin{array}{c}59.5 \\
(12.5)\end{array}$ \\
\hline Secondary school & 188 & $\begin{array}{c}65.0 \\
(12.0)\end{array}$ & \multicolumn{3}{|c|}{ Acquisition of information about puberty } \\
\hline High school\& diploma & 329 & $\begin{array}{c}65.0 \\
(10.9)\end{array}$ & Yes & 955 & $\begin{array}{c}61.5 \\
(13.0)\end{array}$ \\
\hline University & 252 & $\begin{array}{c}66.0 \\
(11.9)\end{array}$ & No & 62 & $\begin{array}{c}64.4 \\
(11.8)\end{array}$ \\
\hline Father's job & & & \multicolumn{3}{|c|}{ Main source of information about puberty* } \\
\hline Unemployed & 22 & $61.7(9.9)$ & Mother \& sister & 614 & $\begin{array}{c}65.2 \\
(11.5)\end{array}$ \\
\hline Worker & 138 & $\begin{array}{c}62.0 \\
(13.5)\end{array}$ & Media & 88 & $\begin{array}{c}64.5 \\
(15.1)\end{array}$ \\
\hline Clerk/retired & 426 & $\begin{array}{c}64.8 \\
(12.0)\end{array}$ & Friends and peer group & 140 & $\begin{array}{l}60.6 \\
(10.8)\end{array}$ \\
\hline Private sector & 335 & $\begin{array}{c}64.8 \\
(11.5)\end{array}$ & Health providers & 106 & $\begin{array}{c}65.0 \\
(12.5)\end{array}$ \\
\hline Experts/Managers & 85 & $\begin{array}{c}62.8 \\
(12.4)\end{array}$ & \multicolumn{3}{|c|}{$\begin{array}{l}\text { Sufficiency of acquired information about } \\
\text { puberty* }\end{array}$} \\
\hline
\end{tabular}




\begin{tabular}{|c|c|c|c|c|c|}
\hline Mother's education* & & & Insufficient & 74 & $\begin{array}{c}59.9 \\
(12.2)\end{array}$ \\
\hline Illiterate \& elementary & 287 & $\begin{array}{c}62.0 \\
(12.3)\end{array}$ & Moderate & 632 & $\begin{array}{c}64.0 \\
(12.0)\end{array}$ \\
\hline Secondary school & 189 & $\begin{array}{c}63.9 \\
(12.1)\end{array}$ & Sufficient & 250 & $\begin{array}{c}66.5 \\
(11.5)\end{array}$ \\
\hline High school \& diploma & 362 & $\begin{array}{c}65.1 \\
(11.2)\end{array}$ & \multicolumn{3}{|c|}{ Preferred source of information about puberty } \\
\hline University & 170 & $\begin{array}{c}66.0 \\
(12.8)\end{array}$ & Mother \& sister & 701 & $\begin{array}{c}64.8 \\
(12.2)\end{array}$ \\
\hline Mothers' job & & & Health providers & 161 & $\begin{array}{c}63.6 \\
(11.8)\end{array}$ \\
\hline Housewife & 841 & $\begin{array}{c}64.0 \\
(11.9)\end{array}$ & Friends and peer group & 124 & $\begin{array}{c}62.0 \\
(11.5)\end{array}$ \\
\hline Employed & 175 & $\begin{array}{c}64.9 \\
(12.6)\end{array}$ & Media & 15 & $64.4(9.0)$ \\
\hline Economic status* & & & Feeling at onset of menarche & & \\
\hline Desirable & 680 & $\begin{array}{c}61.3 \\
(11.9)\end{array}$ & Pleasure & 267 & $\begin{array}{c}64.4 \\
(12.3)\end{array}$ \\
\hline $\begin{array}{l}\text { To some extent } \\
\text { desirable }\end{array}$ & 287 & $\begin{array}{c}61.6 \\
(13.2)\end{array}$ & Unpleasure & 561 & $\begin{array}{c}63.7 \\
(12.1)\end{array}$ \\
\hline Undesirable & 41 & $\begin{array}{c}65.5 \\
(11.4)\end{array}$ & No special feeling & 173 & $\begin{array}{c}65.7 \\
(11.1)\end{array}$ \\
\hline
\end{tabular}

n: Numbers; SD: standard deviation; attainable practice score range was 0-100, higher score indicates better practice

$* \mathrm{P}<0.05$

Table 3. Relationship between practice score and quantitative socio-demographic in adolescent girls according to Pearson test.

\begin{tabular}{lcc}
\hline characteristics & \multicolumn{2}{c}{ practice } \\
\cline { 2 - 3 } & $\mathrm{r}$ & $\mathrm{p}$ \\
\hline Age of student & 0.07 & 0.022 \\
Age of father & -0.04 & 0.220 \\
Age of mother & -0.05 & 0.084 \\
Child's rank family & -0.06 & 0.059 \\
Number of & -0.07 & 0.023 \\
members & & \\
Number of brother & -0.03 & 0.403 \\
Number of older sister & -0.03 & 0.342 \\
Age at menarche & 0.12 & $<0.001$ \\
\hline
\end{tabular}


Table 4. Relationship between socio-demographic characteristics and practice score in adolescent girls according to univariate and multivariate general linear model.

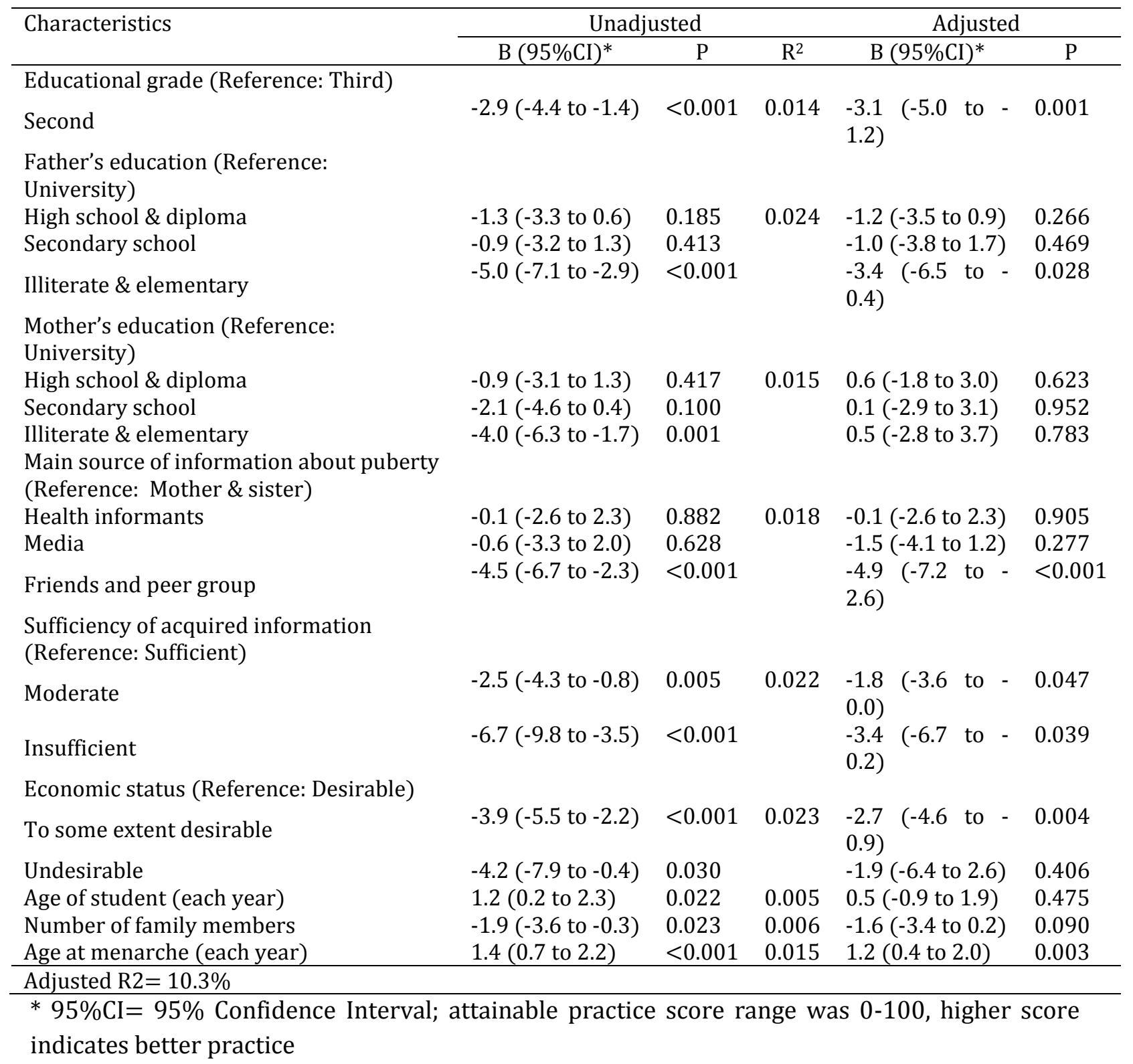

\section{References:}

1. World Health Organization. Adolescent development: Maternal, newborn, child and adolescent health; 2012. Available from: http://www.who.int/maternalchild adolescent/topics/adolescence/dev/en/index.html. Accessed on August 1, 2012. 
2. World Health Organization. 10 Facts on adolescent health 2008; Available from: http://www.who.int/features/factfiles/adolescent_health/en/index.html. Accessed on August 1, 2012.

3. Statistical Center of Iran. National Census of Population and Housing of Iran. 2011; Available from: http://amar.sci.org.ir. Accessed on September 15, 2011.

4. Barooah P. Adolescents' Nutrition, Attitudes and Practices. IJCAES Special Issue on Basic, Applied \& Social Sciences. 2012; 2:308-1.

5. Simon AE, Wardle J, Jarvis MJ, Steggles N, Cartwright M. Examining the relationship between pubertal stage, adolescent health behaviours and stress. Psychol Med. 2003; 33:136979.

6. Parwej S, Kumar R, Walia I, Aggarwal AK. Reproductive health education intervention trial. Indian J Pediatr. 2005; 72:287-91.

7. Kotecha PV, Sangita P, Baxi RK, Mazumdar VS, Shobha M, Ekta M, et al. Reproductive health awareness among rural school going adolescents of Vadodara district. Indian J Sex Transm Dis and AIDS. 2009; 30:94-9.

8. Brownell KD, Schwarts MB, Puhl MB, Henderson KE, Harris JL. The need for bold action to prevent adolescent obesity. J Adolesc Health. 2009; 45:S8-S17.

9. Walker Z, Townsend J, Oakley L, Donovan C, Smith H, Hurst Z, et al. Health promotion for adolescents in primary care: randomised controlled trial. BMJ. 2002; 325:524-7.

10.Grunbaum JA, Kann L, Kinchen SA, Williams B, Ross JG, Lowry R, et al. Youth risk behavior surveillance national alternative high school youth risk behavior survey, United States, 1998. J Sch Health. 2000; 70:5-17.

11. Grunbaum JA, Kann L, Kinchen SA, Williams B, Ross JG, Lowry R, et al. Youth risk behavior surveillance - United States, 2001. J Sch Health. 2002; 72:313-28.

12. Ozer EM, Park MJ, Paul T, Brindis CD, Irwin CE. America's adolescents: are they healthy? San Francisco, California: National Adolescent Health Information Center; 2003.

13. Lowdermilk DL, Perry SH, Bobak I. Maternity and woman's health care. 9th ed. St. Louis: Mosby; 2007.

14. Abioye-kuteyi EA. Menstrual knowledge and practices among secondary school girls in Ile Ife, Nigeria. J R Soc Promot Health. 2000; 120: 23-6.

15. Abdolahi F, Shaaban khani B, Khani S. Study of puberty health educational needs of adolescents in mazandaran province. J Mazandaran Univ Med Sci 2004; 14:56-63. [Persian]

16. Alavi M, Poushaneh K, Khosravi AA. Puberty health: knowledge, attitude and practice of the adolescent girls in Tehran. Payesh Health Monit. 2009; 8:59-65. [Persian] 
17. Baiali Meibodi F, Mahmodi M, Hasani MD. Knowledge and practice of Kerman primarysecondary school girls on menstrual health in the academic. J Yasuj Fac Nurs Midwifery. 2009; 4:54-62. [Persian]

18. Malekshahi F, Farhadi A. Knowledge, attitude and practice of high school girls on menstrual health. Yafteh. 2006; 8:73-78. [Persian]

19. Irinoye OO, Ogungbemi A, Ojo AO. Menstruation: knowledge, attitude and practices of students in IIe-Ife, Nigeria. Niger J Med. 2003; 12:43-51.

20. Bobhate PS, Shrivastava SR. A cross sectional study of knowledge and practices about reproductive health among female adolescents in an urban slum of Mumbai. J Fam Reprod Health $2011 ; 5: 117-24$.

21. Lawan UM, Yusuf NW, Musa AB. Menstruation and menstrual hygiene amongst adolescent school girls in Kano, Northwestern Nigeria. Afr J Reprod Health 2010; 14:201-7.

22. Mirghafourvand M, Mohammad-Alizadeh-Charandabi S, Tavananezhad N, Karkhaneh M. Health-promoting lifestyle and its predictors among Iranian adolescent girls, 2013. Int J Adolesc Med Health. 2013; DOI 10.1515/ijamh-2013-0324.

23. Nagar SH, Aimol KHR. Knowledge of adolescent girls regarding menstruation in Tribal Areas of Meghalaya. Stud Tribes Tribals. 2010; 8:27-30.

24. Sudeshna R, Aparajita D. Determinants of menstrual hygiene among adolescent girls: a multivariate analysis. National J Community Med 2012; 3:294-301.

25. Gupta S, Sinha A. Awareness about reproduction and adolescent change school girls of different socioeconomic status. J Obstet Gynaecol India. 2006; 56:324-8.

26. Lee LK, Chen PC, Lee KK, Kaur J. Menstruation among adolescent girls in Malaysia: a cross-sectional school survey. Singapore Med J. 2006; 47:869-74.

27. Koivusilta LK, Rimpela AH. Pubertal timing and health-related behaviours in adolescence - socioeconomic outcomes in a follow-up study from Finland. Ital J Public Health. 2006; 3: 4152.

28. Kaltiala-Heino R, Marttunen M, Rantanen P, Rimpela M. Early puberty is associated with mental health problems in middle adolescence. Soc Sci Med. 2003; 57:1055-64.

29. Dick DM, Rose RJ, Viken RJ, Kaprio J. Pubertal timing and substance use: Associations between and within families across late adolescence. Dev Psychol. 2000; 36:180-9.

30. Koff E, Rierdan J. Early adolescent girls and understanding of menstruation. J Womens Health. 1995; 22:1-21. 